\title{
PRESS CONTROL AND COPYRIGHT IN THE 16TH AND 17TH CENTURIES
}

\author{
W. S. Holnsworth \\ St. John's College, Oxford
}

For the origins of the law of copyright we must look at the various methods of controlling the press employed by the Tudors and early Stuarts. Three of these methods can be distinguished. Firstly they punished as criminal offenses the publication of treasonable, seditious, heretical, or blasphemous books. Secondly they gave large powers of control over printing and publishing to the Stationers Company, whom they had incorporated mainly in order that they might supervise this new industry; and these powers they supplemented when necessary by direct governmental action. Thirdly they issued comprehensive ordinances based partly on the needs of the state, but chiefly upon the rules which the Stationers Company had devised for the organization and control of printing. With the first of these expedients I do not intend to deal in this paper. My object is to describe the working of the other two expedients. We shall see that as the result of their working unlicensed printing was suppressed, and the conception of copyright was originated. We shall see, too, that the differences between the control exercised indirectly through the Stationers Company, and that exercised directly by the crown, are at the root of two very different theories as to the origin and nature of copyright.

(I) For the beginnings of the associations which in 1556 were incorporated as the Stationers Company we must go back to the fourteenth century. ${ }^{1}$ In 1357 we have evidence of the existence of a society of writers of court hand and text letters. ${ }^{2}$ In 1403 these writers of text letters, and those "commonly called limners (i. e., illuminators), and other good folks, citizens of London, who were wont to bind and sell books" were formed into a craft presided over by two wardens, the one a limner and the other a text writer, whose duty it was to provide for the "good rule and governance" of these allied crafts. ${ }^{3}$ It would seem that about the same period the word "Stationer" was beginning to be applied to the men who thus made

\footnotetext{
${ }^{1}$ For this subject generally see 1,2 and 4 Arber's Transcript of the Stationers' Registers (1875-7).

${ }^{2}$ I Arber, op. cit., ch. 22.

'Ibid., ch. 23-"that the names of the Wardens so elected may be presented each year before the Mayor, for the time being, and they be there sworn well and diligently to oversee, that good rule and governance is had and exercised by all folks of the same trades in all works unto the said trades pertaining."
} 
or dealt in books. ${ }^{4}$ Certainly in 1480 it was applied to persons whose craft consisted in binding, dressing and guilding MSS $;^{5}$ and it is probable, from the account given by Christopher Barker in 1582 , that the word "stationer" was applied to all the various members of this joint craft. ${ }^{\mathrm{s}}$

With the rise of printing changes necessarily took place. The craft of the printers was obviously closely allied to the craft of the stationers; and Barker tells us that the stationers

"have, and partly to this daye do use to buy their bookes in grosse of the saide printers, to bynde them up, and sell them in their shops, whereby they well mayntayned their families."

The stationers thus appear as the persons who bought from the printers the books which they bound and sold. They were the capitalists upon whom the printers depended. ${ }^{8}$ And this view is confirmed by the provisions of the statute of $\mathrm{I} 533^{-4}$, passed to regulate the prices of books and to prohibit the importation of foreign bound books and the retail sale by aliens of any printed books. The preamble to the statute makes it clear that the craft of printing was already allied with book binding and book selling; but the statute itself protects, not the printers, but the book binders, and book sellers, and the book buying public. ${ }^{9}$ Thus it is not surprising to find that when the new craft of printing allied itself with the older association of crafts connected with the production of books, the association was called by the name of its richer and more important members, and became first the craft and then the company of stationers. ${ }^{10}$ From an early date the stationers and text writers had settled round St. Paul's

\footnotetext{
2 Arber, op. cit., 5-6.

${ }^{3} 4$ Arber, op. cit., 24, cites from the accounts of the keeper of the king's great wardrobe in the city of London several disbursements to "Piers Bandwyn stacioner for binding gilding and dressing books."

"In the time of king Henry the eighte, there were but fewe Printers, and those of good credit and of compotent wealth, at whiche tyme and before, there was no other sort of men that were writers, Lymners of books and dyverse things for the Church and other uses called Stacioners." I Arber, op. cit., ch. 20.

'Ibid.

${ }^{8}$ Barker says, "In King Edward the sixt his Dayes, Printers and printing began greatly to increase, but the provision of letter, and many other things belonging to printing, was so exceeding chargeable, that most of those printers were Dryven Throughe necessitie, to compound before hand with the booksellers at so lowe value, as the printers themselves were most tymes small gayners, and often loosers." I Arber, op. cit., ch. 20.

${ }^{9} 25$ Henry VIII, ch. I5; a proviso in I Richard III, ch. 9, which allowed the importation of foreign books was repealed.

${ }^{10}$ They were incorporated on May 4, 1556; and in February, 1560, they were made one of the liveried companies of the city. I Arber, op. cit., 24; for Phillip and Mary's Charter, and Elizabeth's Confirmation, see I Arber, $o p$. cit., chs. 28-32.
} 
Churchyard; and the name Paternoster Row had been given to the street which they chiefly inhabited because there they sold "all sorts of bookes, then in use, namely, A.B.C. or Absies with the Pater noster, Ave, Creede, Graces, etc."11

To this company the Tudors entrusted the general supervision of the trades of printing, binding, publishing, and dealing in books. ${ }^{12}$ Only those free of the company or specially licensed by the crown could print or publish ;3 and there were many complaints when the company's monopoly was infringed by a royal grant permitting the University of Cambridge to set up a printing press. ${ }^{1 . t}$ As with many other trades, so with this, the Tudors gave the company large powers to make orders, to charge fees, to settle industrial disputes, to supervise the education of apprentices, to search for and destroy books printed in contravention of any statute, act, or proclamation. ${ }^{15}$ In return they expected the company to assist the government in preventing the publication of treasonable, seditious, or heretical books, in discovering the authors or printers of any obnoxious works that appeared, and in carrying out the regulations which the government from time to time made. ${ }^{16}$ In the performance of this task the system of registration of published books adopted by the company was an invaluable aid. Unless a printer or publisher had a special patent of privilege from the crown authorizing him to print a certain book, or certain books of a defined class, he was expected to register with the company all books which he printed or published. ${ }^{17}$ On

\footnotetext{
${ }^{11}$ I Arber, op. cit., ch. 25, citing Stow's Survey.

${ }^{2}$ See the Charter, I Arber, op. cit., ch. 3 r.

${ }^{13}$ "No person . . . shall practise or exercise by himself or by his ministers his servants or by any other person the art or mistery of printing any book or any thing for sale or traffic within this our realm of England or the dominions of the same unless the same person at the time of his foresaid printing is or shall be one of the community of the foresaid mistery or art of Stationery of the foresaid City or has therefore licence of us . . . by the letters patent of us." I Arber, op. cit., chs. 30, 3I.

"I Arber, op. cit., ro8; 2 Arber, op. cit., 782, 8I3, 8I9; 4 Arber, op. cit., 527; cf. a remonstrance by the company addressed to Burghley in 1576 , against a proposed monopoly to print all ballads, and all books of under twenty-four pages.

${ }^{15}$ See the clauses of the Charter, note I3, stipra; cf. I Arber, op. cit., 159b, and for some good illustrations of the way in which they exercised their powers see the entries February I, I594, October 23, I597, in 2 Arber, op. cit., 393a, $396 \mathrm{a}$; for an order of 1635 made to settle certain industrial disputes and to regulate the rights of masters and journeymen, see 4 Arber, op. cit., 2I-24.

${ }^{10}$ See the Star Chamber decree of 1566 , printed in I Arber, op. cit., 145b; cf. Documents relating to the Bishop of London's search for and list of printing presses in 1583 , ibid., $107 \mathrm{~b}-108 \mathrm{~b}$; and the orders as to searches and enquiries ( 1576$) 2$ ibid., $5 \mathrm{a}, 5 \mathrm{~b}$; and orders as to printing, ibid., $6 \mathrm{a}, 6 \mathrm{~b}$.

${ }^{17} 2$ Arber, $O p$. cit., 24, 25; for the privileges granted by the crown see infra; occasionally these patents were brought in to be confirmed by the company, I ibid., 32a.
} 
each registration the company was entitled to a small fee. ${ }^{1 s}$ This system no doubt helped to control the press. But registration was not without its advantages to the printer or publisher; and it is this advantage which is interesting to the legal historian.

By registration the printer or publisher got an incontestable title to the book registered in his name. It therefore tended to give clearness and precision to the idea of literary property or copyright. The registers show us the growth of this idea. Copyright is protected by the imposition of penalties upon those who infringed it. ${ }^{19}$ It is assigned, ${ }^{29}$ sold, ${ }^{21}$ settled, ${ }^{22}$ given in trust,${ }^{23}$ and limited grants are made. ${ }^{2+}$ Its duration is nowhere stated, unless it is expressly created for a limited period. ${ }^{25}$ It is therefore most probable that it was perpetual; and if we regard it, as it was then clearly regarded, as a form of property, it would naturally be considered to be perpetual, unless a general enactment or order could be pointed to which expressly limited it. Nowhere can such general enactment or order be found. The only limitation on the privilege and right of the owner of the copy was an order of 1588 that if a book was out of print, and, after warning, the owner did not reprint within six months, any member of the company could do so provided that the author did not refuse, and the owner of the copyright was given such part of the profit as the master and wardens of the company might order. ${ }^{26}$

\footnotetext{
${ }^{13}$ Ibid.

${ }^{10}$ See e. g., I Arber, op. cit., I2rb-“"Received of Alexandre lacye for his fyne for that he printed ballettes which was other mens copyes. XIId;" such entries are frequent; see e. g., I ibid., 34b-35a for a list.

${ }^{20} 3$ Ibid., Ira (1596)-“Assigned over unto him (William Leeke) for his copie from master harrison the elder, in full court holden this day by the said master harrison's consent A booke called Venus and Adonis; ibid., $78 \mathrm{a}$ (1602)an assignment of Stowe's Chronicle; ibid., 406-407 (1638)-an assignment of "all the estate right title and interest" in 68 works-"Salvo jure cujuscunque;" for an entry saving the rights of a particular person see 2 ibid., 2833 (159I).

${ }^{21}$ I Ibid., II4; this entry of July 22, 1564, is the earliest entry of such a sale; it runs as follows: "Receavyd of Thomas Marshe for his lycence for pryntinge of Dygges Pronostication and his tectonicon which he boughte of lucas haryson."

${ }^{2} 3$ ibid., I75a (1608)-“John Tapp and Thomas Mann Junior Entered for their copy parte and partelike betweene them duringe their lives only a booke called the art of Navigacion. As eyther of them shall dye his moyty shall fall to the disposicion of the Company."

${ }^{23} 3$ ibid., 123a (1605)-"Memorandum it is agreed that these copies thus entred for Edmund weaver may and shall be at the Disposition of master Thomas Wight to dispose of them to any freeman of this Companye"

${ }^{24} 3$ ibid., 120b (1605) - "Grannted unto him the printing of one impression onely . . . paying to the use of the poore $21 d$ in the li. for paper and printing. And agreying with master norton for suchie numbers thereof as he hath unsold of the former impression." Ibid., I76b (1608)-Two licences to print one impression only.

${ }^{25}$ See note 22 , supra.

${ }^{23} 2$ Arber, op. cit., 6a.
} 
From the point of view of legal history the invention of this new form of property is the most important result of the control over the press exercised by the Stationers Company in the sixteenth and early seventeenth centuries. But the Tudors, though they gave large powers to companies of this kind, sometimes intervened to control directly the industries subject to their supervision. This occurred in the case of the press as in the case of other industries. And just as in the case of other industries this control gave rise to the conception of a patent "right," so, in the case of the press, it gave rise to further developments in the conception of copyright.

In the sixteenth century the crown controlled other industries by granting patents of monopoly to certain favored persons. It adopted the same plan with regard to the printing and publishing industry. Patents were issued to certain persons giving them the exclusive privilege of printing certain books or certain kinds of books for a certain period. ${ }^{27}$ Thus, to take a few out of many instances, in I559 R. Tottell had a privilege to print during his life "all manner of books concerning the common laws of this realm;"'2s and W. Seres had a privilege for his life to print Primers and books of private prayers. ${ }^{29}$ In 1589 T. Bright, M.D., had a privilege for fifteen years to print all works in shorthand and any other works he might compile. ${ }^{30}$ In 1623 George Wither the poet was given an exclusive privilege for fifty-one years in his Hymns and Songs of the Church and certain other privileges. ${ }^{31}$ In the majority of cases these privileges were given to the printers; and in many cases to the company of stationers. ${ }^{32}$ In fact the company sometimes protested against privileges being granted to other persons. ${ }^{33}$ It would appear from Barker's report to Burghley in 1582 that these privileges. were granted in many cases to printers, who were impoverished owing to the fact that the most profitable copyrights had become the property of the booksellers ${ }^{34}$ and that these grants of privileges were

\footnotetext{
"See I Arber, op. cit., II5, II6, I44, for the part of Barker's report of 1582 describing the patents then in force; 2 ibid., 15,16 , for a list between the years 1559 and 1599 .

${ }^{23} 2$ ibid., I5.

so Ibid., 16.

${ }^{2}$ Ibid.

${ }_{4}^{31}$ ibid., 13.

${ }^{*} 3$ ibid., 42-a grant by James I in 1603 of the privilege to print Primers. Psalters, Almanacks, and Prognostications for ever; ibid., 317, 3I7b-a second and larger grant to the same effect in $16 \mathrm{i} 6$.

${ }^{3}$ See 4 ibid., 12-20, for an account of the controversy, literary and otherwise, between Wither and the Stationers Company; on Wither's petition the Council had ordered the Stationers to respect his rights and privilegesapparently without much effect. S. P. Dom. 1633-4 533, CCLXIII 80.

36 "The Bookesellers being growen the greater and wealthier member have nowe many of the best Copies and keepe no printing howse, neither beare any charge of letter or other furniture but onlie pay for the workmanship . . . so that the artificer printer growing every daye more and more unable to provide letter and other furniture, requisite for the execution of any good
} 
not considered by Parliament to be contrary to public policy can be seen from the fact that the Act of James I which regulated monopoly patents provided that it should not extend to "any letters patent or grants of privilege heretofore made or hereafter to be made of, for, or concerning printing." 35 The great legal interest of this device consists in the fact that it introduced two new ideas into the conception of copyright. In the first place copyright no longer depended solely upon the registration by a member of the company of the particular book. It might originate in a grant from the crown, and therefore might belong not only to a member of the company but to anyone else. This device therefore helped to introduce the idea of the author's copyright side by side with the copyright of the publisher or printer. In the second place these patents introduced the idea of a copyright limited as to duration. Many of these grants were so limited, ${ }^{36}$ and this, as we have seen, was a conception that does not appear so clearly with respect to copyright acquired by registration with the company.

But this method of controlling the press through the company of stationers, and by means of monopoly patents granted to printers, publishers and others, was satisfactory neither to the state nor to the industry itself. The state in its warfare against nonconformists political and religious found that it needed more stringent rules and a better machinery for their enforcement. The industry itself suffered from these monopoly patents, because, the privilege to print a large number of the most profitable books having become vested in a favored few, there was no chance for the journeymen to rise in their trade and become master printers. At the same time, as there was no adequate limitation upon the number of apprentices which a printer could take, the number of these discontented journeymen was constantly increasing. They formed an organization which systematically pirated the books belonging to the patentees. ${ }^{37}$ Concessions were made and a peace was patched up. ${ }^{3 s}$ But the result of this controversy, which was being carried on between the years 1578 and $\mathrm{I} 586$, was the assumption by the government of a direct control

work . . will in tyme be ... prejudiciall to the commonwealth. These considerations have enforced printers to procure granntes from her Majestie of some certayne Copies for the better mayntenance of furniture, Correctours and other workmen, who cannot suddaynely be provided, nor suddenlye put away: and if they shoulde, must of necessitie either wantt necessarie lyving or print bookes, pamphletts, and other trifles, more daungerous than profitable." I Arber, op. cit., II4, 115.

${ }^{35} 2 \mathrm{I}$ James I, ch. 3, sec. Io. $\quad{ }^{36} 2$ Arber, op. cit., 15, I6.

${ }^{37}$ For an account of this controversy see 2 Arber, op. cit., 17-2I; for some cases in the Star Chamber bearing upon it see ibid., 753-769, 790-793, 794-800, 800-804.

${ }^{33}$ Ibid., 784-5; see ibid., 786-789, for the list of copyrights presented by the patentees for the use of the poor of the Stationers Company. 
of the press. The Stationers Company still retained its rights, powers and privileges. But, for the future, it was more closely supervised by the government, and its regulations became merely supplementary to the comprehensive ordinances issued by the government.

(2) The two detailed ordinances which controlled the press were issued by the Star Chamber in I586, and 1637 . It is to these two ordinances that we must look for the origin of the licensing laws. At the same time they recognize the new legal conception of copyright to which the regulations of the company and the patents of the crown had given birth.

That the somewhat general orders hitherto issued by the Council and the control exercised by the company of stationers were insufficient means of restraint had been for some time apparent. In I 577 William Lambarde had drawn an Act, "to restraine the licentious printing, selling and uttering of unprofitable and hurtful Inglishe books," and had further corrected it in $15800^{30}$ According to this Act the press was to be subjected to the control of certain governors, without whose license nothing was to be printed or published. The disorders in the company had emphasized the need for a general regulation of this kind; and therefore in $1586^{40}$ an ordinance, much more comprehensive than Lambarde's Act, was issued by the Star Chamber.

All presses were to be notified to the company. No printing was to take place in any place except London, Oxford and Cambridge. The archbishop of Canterbury and the bishop of London were to decide as to the number of presses needed; and no new press was to be set up till the number of presses had fallen below this limit. The company, the archbishop, and the bishop were to act together in choosing a new master printer when a new appointment became necessary. All books must be licensed by the archbishop and bishop, except books issued by the Queen's printer for the Queen's service, and except books of the common law which were to be licensed by the two chief justices and the chief baron. No books contrary to any statute or royal injunction were to be printed; and no books contrary to

"any letters patentes commissions or prohibicions under the great seale of England, or contrary to any allowed ordynannce sett downe for the good governaunce of the Cumpany of Staconers."

This last provision, it will be observed, prevented printing in breach of copyright. The number of apprentices which master printers could take was limited; and power was given to the company to search for and deface offending books, presses, and type. Printers, publishers, booksellers, or binders who took part in the issue of books

\footnotetext{
${ }^{30} 2$ Arber, op. cit., 751-753. $\quad$ "Ibid., 807-812.
} 
contrary to this ordinance made themselves subject to prosecution before the Court of High Commission. ${ }^{4 x}$

The ordinance of $1637^{42}$ is far more elaborate. It was caused partly by the recrudescence of trouble between the journeymen and the master printers, but chiefly by the growing intensity of the political and religious controversies of the day which seemed to require a more stringent control of the press. Thus, while the main part of the ordinance is concerned with licensing regulations, we get provisions designed to remedy the grievances of the journeymen, and to protect the copyrights of the printers and publishers. The provisions of the ordinance were to be enforced either in the Court of High Commission or in the Star Chamber.

In the first place it prohibited the publication or importation of all unlicensed books, and provided an elaborate scheme of licensing, together with subsidiary provisions designed to make it impossible that any unlicensed books should appear. Books of law were to be licensed by the two chief justices and the chief baron; books of history and politics by the secretaries of state; books of heraldry by the earl marshal; and "all other books, whether of Divinitie, Phisicke, Philosophie, Poetry or whatsoever" by the archbishop of Canterbury and the bishop of London. All books were to bear the names of the printer and the author. No one who had not served a seven years' apprenticeship to the trade of bookseller, printer, or book binder was to trade in books. No more than twenty master printers were to be allowed; and no one of them was to have more than two presses, except one who had been master or upper warden of the Stationers Company, in which case he might keep three. No one was to erect or manufacture a press or cast type without notice to the company. Only four type founders were to be allowed. The number of apprentices which a master printer might have was limited. Large powers of search were given to the Stationers Company to discover breaches of the ordinance. Books imported were to be landed only at the port of London.

In the second place the ordinance directly assisted the journeymen by provisions that only apprentices or free men of the company were to be employed to print, and that the company must take measures to provide employment for all journeymen who were out of work. A master printer was to be obliged to give work to at least one such journeyman if required to do so; and conversely a master printer could require any journeyman out of work to enter his employment. ${ }^{43}$

\footnotetext{
"For an instance of such a prosecution see S. P. Dom. (I63I-3) 3, CLXXXVIII 13.

${ }^{2} 4$ Arber, op. cit., 529-536.

${ }^{2} C f$. the rules that an edition should consist only of a limited number of copies that work might be provided for the journeymen, 2 Arber, op. cit., 6a; ibid., 883-a similar order of 1587 .
} 
Imdinrectly ilt assisted the jourmeymen by a prowision that mo Emglisth book should be printed beyomd the seer amd inmponted.

In the thind place copyright wras protected by a clanse withich prohintitted the forgerty of the rmank of the compentu upon any book, or of the mark of ariy persom who lhad a privillege to primit the books. Surch books were not to be primted witthoult the consemit of the company or the persons having the privillege to primit.

The ordinance thus sums up and codiffies the policy pursued during this period with regard to the press. The provisions as to licensing outline the policy which was pursued almost continuously till I694 The industrial provisions in favor of the joumeymen and the powers of supervision given to the compasty of stationers simply apply to this indwstry the same policy as was pursued with reference to many other industries. The provisions protecting the rights of authors, printers or publishers to the sole privilege of printing certain books contain the germs of the law of copyrighte. But we shotald do well to note that, under these provisions, copyright is closely bound up both with the privileges of the Stationers Company, and with the patents issued by the crown giving an exclusive privilege to print; and we shall see that this double origin of copyright has been the source of very different theories as to its nature. Here as in many other cases, the manner in which a right first gained adequate protection and recognition has had a large influence upon its future development. ${ }^{* 4}$

The victory of the Parliament destroyed all this machinery for the control of the press, because it depended directly for its existence and motive power upon the prerogative of the crown and the courts of Star Chamber, and High Commission. What policy would the Parliament pursue? The matter did not long remain doubtful. A revolutionary government is peculiarly open to attack and peculiarly sensitive to criticism. The company of stationers and all the industries which they represented feared that unlicensed printing would mean the loss of the valuable copyrights belonging to the company itself, and to its members.

In a petition which they addressed to Parliament' they pointed out that an unlicensed press was a danger to religion and to the state; that the company was best fitted to be entrusted with the control of this industry ; ${ }^{\text {ar }}$ and, further, that unless the industry was regulated,

\footnotetext{
"See infra. $\quad$ I Arber, op. cit., 584-58s.

"It is not meere Printing, but well ordered Printing that merits so much favour and respect, since in things precious and excellent, the abuse . . . is commonly as dangerous, as the use is advantageous. . . . We must in this give the Papists their due; for as well where the Inquisition predominates, as not, regulation is more strict by far, than it is amongst Protestants, we are not so wise in our Generation, nor take so much care to preserve the true Religion, as they do the false from alteration."

" "The Stationers humbly desire to represent three things to the Parliament: (I) that the Life of all Law consists in prosecution. (2) That in matters of
} 
there was no security for copyright without which the industries they represented would perish. ${ }^{48}$ The destruction of copyright, they said, was the destruction of a species of "property," the existence of which could be justified upon the same grounds as any other species of property. ${ }^{49}$ Community of copies would make the trade in books hazardous, and be hurtful to the state, the trade, and the public. It would discourage authors from writing, and ruin orphans and widows whose estate consisted in the income derived from their copyrights. It would impoverish the company itseif because its chief wealth consisted in copyrights, and it would be therefore the less able to regulate the industries it represented, and to give pecuniary assistance to the state. Finally, unless some sort of regulation was made there was no security against the importation of objectionable books from abroad, and no protection for the native industry. Milton pointed out in vain that it was perfectly possible to suppress mischievous and libellous books, and to protect copyright privileges without a system of licensing. ${ }^{50}$ In vain he asked the Parliament

"to consider what nation it is whereof ye are and whereof ye are the governors: a nation not slow and dull, but of a quick ingenious and piercing spirit, acute to invent, subtle and sinewy to discourse, not beneath the reach of any point the highest that human capacity can soar to."

In vain he reminded them that "errors in a good government and in a bad are equally almost incident." His advice to Parliament to treat its detractors with contempt fell on deaf ears; and his vision of the nation,

the Presse, no man can so effectually prosecute, as Stationers themselves. (3) That if Stationers at this present do not so zealously prosecute as is desired . . . that it is partly for want of full authority, and partly for want of true encouragement."

us "It (propriety of copies) is not so much a free privilege as a necessary right to Stationers; without which they cannot at all subsist."

10 "There is no reason apparent why the production of the Brain should not be as assignable, and their interest and possession ... . held as tender in Law, as the right of any Goods and Chattells whatsoever."

${ }^{50}$ "And as for regulating the Press, let no man think to have the honour of advising ye better than yourselves have done in that order published next before this; that no book be printed, unless the printer's, and the author's name, or at least the printer's be registered. Those which otherwise come forth, if they be found mischievous and libellous, the fire and the executioner will be the timeliest and the most effectual remedy that man's prevention can use;" "And, how it (the present order) got the upper hand of your precedent order . . . it may bo doubted there was in it the fraud of some old patentees and monopolizers in the trade of bookselling, who, under pretence of the poor in their company not to be defrauded, and the first retaining of each man his several copy, which God forbid should be gainsaid, brought divers glorying colours to the House." 
"as an eagle renewing her mighty youth, and kindling her undazzled cyes at the full mid-day beam, purging and unscaling her long abused sight at the fountain itself of heavenly radiance, while the whole noise of timorous and flocking birds, with those that love the twilight, flutter about, amazed at what she means,"

remained merely a vision. Milton's Areopagitica was, to use his own words, "a strain of too high a mood" to be appreciated by a mere representative assembly.

The ordinances of the Commonwealth all proceeded upon the lines indicated by the petition of the Stationers Company, and show a gradual approximation to the provisions of the Star Chamber ordinance of 1637 . The ordinance of $1643^{51}$ prohibited any publication of the orders of either House except by order of the House; and no other book was to be "printed, bound, stitched or put to sale" unless both licensed and entered in the Register of the Stationers Company. ${ }^{52}$ The copyrights of the company and private persons were not to be infringed, either by printing or importing printed copies. Extensive powers of search and arrest were given to the company in order that these provisions might be duly carried out. The ordinance of $I 647^{53}$ provided again for the licensing of all printed matter, and ordered that the author, printer and licenser's name should be on every book. The members of the committees for the militia in London, Middlesex and Surrey, justices of the peace, and head officers of corporations were to see to its enforcement. In $1649^{54}$ a still more elaborate ordinance was issued still more closely modelled on the Star Chamber ordinance of 1637 . In addition to provisions as to licensing, printing presses were restricted to London, the two Universities, York, and one press in Finsbury used to print the Bible and the Psalms; printers must enter into a bond of $£_{300}$ to observe the ordinance; and no house could be let to a printer nor implements for printing manufacturing without notice being given to the Stationers Company. Imported books must be landed in London only, and viewed by the master and wardens of the company before they were sold; and no books printed in this country were to be imported. Copyright was not to be infringed. Hawkers of pamphlets and ballad singers were suppressed. In $1652-3,{ }^{55}$ the whole business of printing was put directly under the control of the Council of State, who were to limit the number of presses, master printers, and apprentices. The

"I Acts and Ordinances of the Interregmun (Firth and Rait) I84-I87.

"A list of licensers is appended to the act; the categories are, law books, physic and surgery, civil and canon law, heraldry, small pamphlets, portraitures, pictures, and the like, mathematics, almanacs, and prognostications; only matter printed by order of either House or of the committee for printing escaped.

${ }^{63}$ I ibid., I02I-1023. $\quad$ "4 2 ibid., 245-254.

${ }^{2} 2$ Acts and Ordinances of the Interregmm, 696-699. 


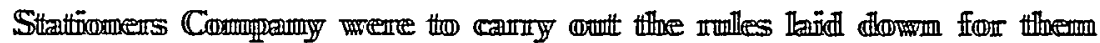
thy the Consmocill.

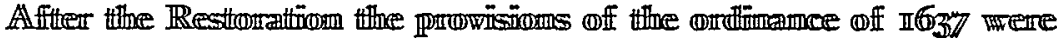
in sulfostamce

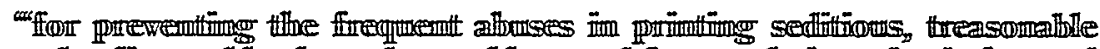

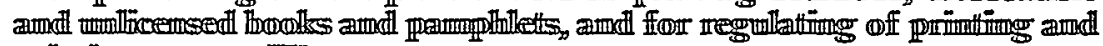

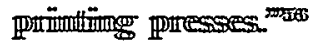

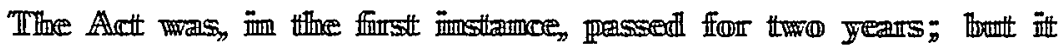

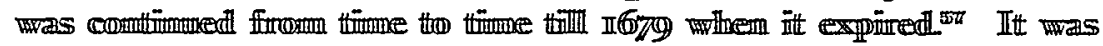
mewived agyain ffor sem years in I685 IIts effect was to give

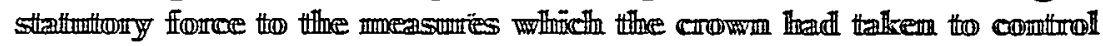

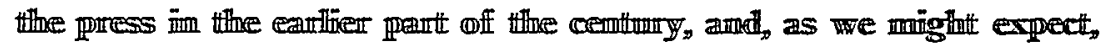

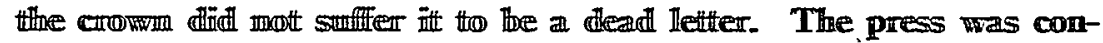

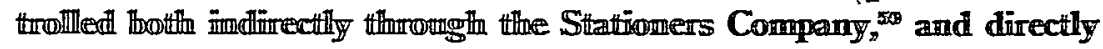
by the lincemsers ampointed loy the crown. In 1662 L'Estrange was appointed licemser; and he, as Atber truly says, "gagged the Londom Press then, as it has newer been gagged before or since" Copyriginit cases were still heard by the Council,sil and the crown availed itself of the inmmumitty of the printing trade from the provisions of James I's statute of momopolies to grant both to individuals and to the company of stationers pattents giving the sole privilege of primting books accasionally a monopoly of this kind was promounced to the void, when it gave a sole privilege to print such things

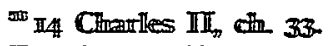

a" If6 Chariles III, cln, 8; I7 Chaurles II, che 4

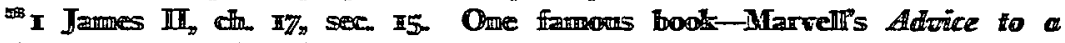

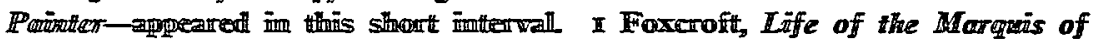
IHcaluffex (I8gS) 172.

sme e g. S. P. Dom (I6/1) 447 for an order of the king to the city of Londoin to see that all printers beliong to the Stationers Company and so are subject to their rules, a course recommended by L'Estrange in the preceding year. Iford. (16\%0) $436-7$; in 1690 an order was issued to that company to search for all unlicensed scandalous books and pamphlets, S. P. Dom. (1690-91) $74 ;$ in 1669 the company had been ordered to cooperate with L'Estrange, S. P. Dom. (1668-9) 446; and in 1670 the king promised to give him if necessary larger powers. Ibid. (1670) $45 \mathrm{I}-2$

"The Term Catalogues $x$ Arber, op. cit., preface XIII; for an interesting report by L'Estrange to Williamson see S. P. Dom. (1667-8) 357-8 - it is not easy to govern the license of the press, and those who serve therein should be rewarded. If you cannot make sure of destroying the offenders utterly, it will be better to let them alone till an opportunity offers of making them sure." For a dispute between him and the Stationers Company in the course of which a quo zuarranto was issued against their charter, see ibid. (1673) 413.

" $U p$ and to attend the Council, but all in vain, the Council spending all the morning upon a business about the printing of the Criticks, a dispute between the first Printer, one Bee that is dead, and the abstractor, who would now print his abstract, one Poole." Pepys, Diary, 64.

Esupra.

c "Prohibition to any person to print for five years any portions of the history of the Worthies of England, compiled by Dr. Thos. Fuller, excepting 
as blank writs, which by no stretch of the imagination, could be classed. as books or pamphlets. ${ }^{64}$ But generally they were upheld, and the prerogative of the crown to make these grants was asserted in the widest terms. Thus a sole privilege of printing almanacs was defended on the ground either that the almanac was part of the book of common prayer, and therefore based upon "a public constitution," so that the king had the sole privilege to print it, or that it had no certain author and therefore the copyright, being a sort of res nullius, vested in the king. ${ }^{65}$ In another case the sole privilege of the king to print psalters and primers was said to rest upon the fact that he was head of the church; and that he could restrain and license prognostications of all kinds because otherwise it would be of dangerous consequence to the government. ${ }^{68}$ Similarly the king was said to have the sole privilege to print books dealing with matters of state or with law; and, that being so, he could grant this privilege to others; and non-possessors of such a privilege were under a duty not to print such books. No one, it was said, could discuss matters of state without his sanction ${ }^{67}$ while the copyright of all law books must belong to him because the laws were the king's laws. ${ }^{68}$ Even the legend about the official reporters of Year Books was pressed into the service of those who argued for the king's patentee-the king had paid for their production and therefore he alone had a privilege to print them, ${ }^{69}$

his son John Fuller, to whom the copyright belongs." S. P. Dom. (1663-4) 67 ; in 1664 Clarendon asked the secretary, Benet, to give Samuel Butler a license for the sole printing of the first, second, and third parts of Hudibras. Ibid. (1664-5) 139; in 1675-6 Robert Scott the publisher of Selden's MSS. wanted a license of sole printing for twenty years. Ibid. (I675-6) 542 .

${ }^{\text {"Monison }}$ v. Lyster (1632) W. Jones 231-2-the grant was of, "le sole fesans de touts bills et informations destre preferre ou exthibite devant le Councell de Yorke in partibus borealibus;" the same point was decided in Earl of Yarmouth v. Darrel (1686) 3 Mod. 75; cf. 2 Roll. Ab. 214, pl. 4.

os "There is no difference in any material part betwixt this almanack and that which is put in the rubrick of the Common Prayer. Now the almanack that is before the Common Prayer proceeds from a public constitution . . . so that almanacks may be accounted prerogative copies. . . . There is no particular author of an almanack; and then, by the rule of our law, the King has the prerogative of the copy;" The Company of Stationers v. Seymour (I677) I Mod. 257. Cf. The Company of Stationers v. Partridge (I7II) Io Mod. I05.

${ }^{*}$ The Company of Stationers v. Lee and Others (1682) 2 Shower, *259, *260.

or "Matters of State and things that concern the Government were never left to any man's liberty to print that would." The Company of Stationers v. Seymour, supra, 257, 258.

es "The king hath a particular prerogative over law books, and so he would have had, if the art of printing had never been known. The reasons are, I. All the laws of England are called the King's laws," The Stationers $v^{-}$. the Patentees about the printing of Roll's Abridgement, Carter's Rep. 89, 9I; cf. S. P. Dom. 1667-8 481-2.

${ }^{89}$ Ibid., 9I-"the salaries of the Judges are paid by the King; and reporters in all Courts at Westminster were paid by the King formerly;" cf. Millar $v$. Taylor (1769) 4 Burr. 2303, 2327 per Willes J. citing a note of Lord Hardwicke's judgment. 
and rights that others should not print them. So far were these rights pushed that when the king's patentees had got hold of the MS. of the third part of Croke's reports and printed it without the consent of the owner, the House of Lords refused to give the owner any redress. ${ }^{70}$ We shall see that the result was to perpetuate the confusion introduced by the Star Chamber ordinances, as to the principles upon which the law of copyright was based. ${ }^{71}$

No immediate change was made in the licensing laws at the Revolution. As Macaulay has said, the restrictions imposed by them "were in perfect harmony with the theory of government held by the Tories," while "they were not in practice galling to the Whigs" because the new licenser, one Fraser, was a zealous Whig. But the existing Act expired in 1692; and at that time the injudicious conduct of Bohun, Fraser's successor, had, by arousing the party feelings of the Whigs, called pointed attention to the shortcomings of the law, and raised the whole question of the control of the press. Tracts, consisting largely of garbled extracts from the Areopagitica, brought Milton's arguments before the public. ${ }^{72}$ And these arguments, coupled with the change which the Revolution was producing in men's political ideas and in the economic and industrial policy of the state, ${ }^{73}$ worked together to produce a body of opinion hostile to the licensing system which had so long prevailed. The licensing laws obviously gave large powers to the crown, and authorized many interferences with individual liberty. On these grounds the Whigs were naturally opposed to them. They also interfered with the liberty not only of the printing trade, but also with the industries of book binding, book selling, type founding, and printing press making; and, as we have seen, exclusive privileges given to print certain kinds of books prevented authors from freely disposing of their works, and might easily prevent a book from being printed at all. These results naturally attracted both a political and a literary opposition; and that the trades affected by the Act desired some change can be seen from the fact that in 1692 representatives of these trades petitioned the House of Lords to hear them before they renewed the Act. ${ }^{74}$ In that year a minority in the House of Lords wished to refuse to renew the Act of Charles II; and, following Milton's suggestion, to allow any book to be printed, provided that the name of the author and printer appeared on it. Their protest illustrates very well the nature of the various kinds of objections-philosophical, political, and economic-that were beginning to accumulate against this legislation.

${ }^{70}$ Roper v. Streater (1672) cited in Company of Stationers v. Parker (I686) Skin. 234 .

${ }^{7}$ Supra.

${ }^{72}$ See 3 Macaulay, History of England (1864) 398-405.

${ }^{73} \mathrm{Ibid}$.

"Journals of the House of Lords (March 4, 1693). 
The present law, it was said,

"subjects all learning and true information to the arbitrary will and pleasure of a mercenary and perhaps ignorant licenser ; ${ }^{75}$ destroys the property of authors in their copies ; and sets up many monopolies."

These objections did not then prevail, and the Act was renewed for two years. But the question of the policy of the law had been brought into prominence; and during the ensuing two years the objections to it were gradually realized by an increasing number of persons. They prevailed with the House of Commons, which, in I694, declined to renew the Act. The House of Lords wished to renew it. But at a conference the House of Commons produced eighteen reasons against its renewal, which are said to have been drawn up by Locke; and these reasons appear to have convinced the House of Lords. ${ }^{77}$ Some of them are based on logical absurdities which were discovered in the provisions of the Act. The Act, it was said, did not accomplish the end for which it was designed. It was designed to suppress treasonable and seditious books; but no particular penalty was imposed for the publication of these books, which were left to be dealt with by the common law. On the-other hand it penalized conduct which in no way concerned the safety of church or state. Neither House of Parliament could authorize the printing of documents which they might think it desirable to publish. Custom house officers must open packets of imported books in the presence of one of the company of stationers; but how can it be known that the packet contains books till it is opened? Smiths must not make iron work for presses without notice to the company; but how can a smith know whether any particular piece of iron work is to be used for a press? Other reasons were based upon the powers of oppression which the Act gave to the licenser and the company, and the arbitrary penalties which might be imposed under it. Others were based upon the new ideas which were beginning to prevail as to the injustice of fettering unduly the freedom of the individual. Why should the trade in books be confined to the port of London? Why, when imported, should they wait an indefinite time till they have passed the licenser? Why should restrictions be placed on the industries of type founding and bookselling? Why should the number of workmen be restricted? Why should there be an obligation to employ workmen when there was no work for them to do?

\footnotetext{
${ }^{75} C f$. Selden Table Talk IX-"Who must be judge? The customer or the waiter? If he disallows a book, it must not be brought into the kingdom; then lord have mercy upon all scholars."

"Journals of the House of Lords (March 8, 1693); cf. 2 Foxcroft, op. cit., I67.

${ }^{\pi 7}$ Journals of the House of Lords (April I8, I695); Journals of the House of Commons (April r7, 1695); 4 Macaulay, op. cit., 78.
} 
Other reasons were based upon the hardships to authors. They were fettered by the rights of patentees, whose privileges were based upon crown grants of doubtful validity, and by the privileges and rights of the company of stationers who could hinder, perhaps from corrupt motives, the publication of useful books. Other reasons were based on the harm done to learning. The most useful and essential books were monopolized by the patentees. These were often badly printed; and, as foreign editions of such books could not be imported. scholars could not get the best editions.

These arguments are on a different plane from those which Milton used without success. But, because they were suited to the temper of the times, and to the comprehension both of the assembly which used them and of the assembly to which they were addressed, they succeeded where Milton failed. The Licensing Act disappeared for ever; and with it disappeared the whole of the machinery for the regulation of the printing and other cognate trades which had been laboriously built up by the Tudor and early Stuart kings, in substance continued under the Commonwealth, and given Parliamentary sanction after the Restoration.

There is reason to think that Parliament did not mean to abandon completely the older policy. Two petitions, similar to those addressed to Parliament in $1643,{ }^{78}$ had been presented to the House of Commons. One from the company of stationers represented the danger that would ensue to the owners of copyrights if nothing was substituted for the Act. ${ }^{79}$ The other from members of the printing trade pointed out the dangers of leaving the trade open, and the advantages of restricting the number, of workmen and apprentices. ${ }^{80}$ The House of Commons appointed a committee to prepare a bill to establish a new set of regulations for the printing trade; ;1 $^{81}$ and it may well be that the knowledge that such a bill was contemplated caused the refusal to renew the Licensing Act to pass without remark. But this bill never matured, and so the whole of the older law disappeared.

The legal results were important, and not unlike those which flowed from the destruction of other prerogative powers. On the one hand the importance of common-law principles was increased. The press, having been freed from the control of a licenser, remained subject only to the restrictions imposed by the law of libel. Hence in the

${ }^{78}$ Supra.

${ }^{79}$ Journals of the House of Commons (March 30, 1694-5).

${ }^{80}$ Ibid. (April I, 1694-5).

${ }^{81}$ Ibid. (February Ir, I694-5). On February 27, other members were added; March 2, bill presented; March 7, read a first time; March II, order for second reading; April $x$, read a second time; April 3 , additional powers given to the committee; for another bill introduced into the House of Lords in I698-9 which attempted to regulate the press nuch in the old way, which failed to pass that House, see House of Lords MSS. iii 27I, no. I339; 4 ibid., 420, no. I706. 
following period the law of libel attained a greatly increased importance in public law, which contributed materially to its elucidation and development. On the other hand much was swept away that it was soon found necessary to replace in an altered form. Copyright had so long depended upon the privileges granted by the crown and the rights connected therewith, and had been so long protected by the penalties provided in the Licensing Act, that the withdrawal of these rights and privileges and the abolition of these penalties left its legal position very obscure. Did it really exist? And, if so, how was it to be protected? The necessity for dealing with this problem caused the passing of the Copyright Act of $1709,{ }^{82}$ which is the starting point of the development of the modern law on this sub-. ject. ${ }^{83}$ With the ascertainment of these results we have reached the conditions under which the development of the various branches of our modern law relating to the press will take place in the following period.

It is in the developments of this period in the law relating to the control of the press that we must look for the origins of copyright antecedent to the Act of I709. Those origins must, as we have seen, be sought partly in the action of the Stationers Company, and partly in the action of the crown. The Stationers Company had so protected copyright that it had come to be in substance a "property" right ${ }^{84}$ and their powers to give protection having been recognized by the common and statute law, ${ }^{85}$ there was good ground for holding that a right of copyright existed at common law. But we have seen that the right was also based upon royal patents giving an exclusive privilege to print $; 88$ and that both the rights and privileges gained by registration with the company and the privileges and rights granted by these patents were protected in the earlier part of the seventeenth century, by the courts of High Commission and Star Chamber, and, in the latter part of the century, by the remedies provided by the Licensing Act. Plaintiffs naturally had recourse to these remedies, and not to ordinary actions for damages at common law; and this gave rise to the view that copyright was not so much a "right of property" recognized by the common law, as a right dependent upon royal grant exercised directly in favor of a patentee, or indirectly through the powers conferred by the crown on the company. As all the cases of copyright reported during this period turned on the

828 Anne, ch.' 'I9.

83 The owners of copyright had petitioned Parliament for a bill to protect their copyrights in 1703,1706 , and 1709.

${ }^{81}$ Supra.

ss Supra.

${ }^{85}$ Charles II, ch. 33, sec. 5, distinctly recognizes that copyright is gained either by virtue of royal letters patent or by registration with the Stationers Company; for an interesting case turning upon such registration see 2 Genealogical History of the Croke Family, App. XXX 855-7. 
privileges of these royal patentees, the privilege was naturally treated by the courts as dependent upon royal grant.

In the eighteenth century the question whether or not it existed at common law, independently of royal grant, was elaborately argued in the case of Millar $v$. Taylor. ${ }^{87}$ The majority of the court of King's Bench decided that it was a "right of property" which existed at common law. But shortly afterwards the decision of the House of Lords in Donaldson v. Beckett $t^{8 s}$ that copyright depended solely on the Act of 1709 made the question one of merely academic interest. It was a question, however, upon which the most divergent opinions continued to exist. In I854 this divergence clearly appeared in the opinions of the judges and in the judgments of the House of Lords in the case of Jefferys $v$. Boosey. ${ }^{\mathrm{so}}$ But it can hardly be doubted that, as a matter of history, the view taken by the majority of the judges, both in this case and in the cases of the eighteenth century, that it existed at common law, is correct. ${ }^{p 0}$ Many of these judgments, and notably the judgment of Erle, J., in Jefferys v. Boosey, display a remarkable historical insight into the origins and mode of development of this branch of the law. As Erle, J., points out, and as the history which I have just related shows, the mere fact that we get hardly any common-law actions for infringement of copyright before the Act of $I 709$ is not conclusive against the existence of copyright at common law. Their absence is fully accounted for by the fact that more convenient remedies then existed which plaintiffs naturally employed.91 To suppose that the right depended on royal patents or on these special remedies is to ignore the manner in which the Stationers Company had, without any reference to these patents or these remedies, built it up on the basis described by Erle, J., as "the most elementary principles of securing to industry its fruits, and to capital its profits." ${ }^{\text {p2 }}$

\footnotetext{
${ }^{87}$ (1769) 4 Burr. 2303. ${ }^{88}$ (I774) 4 Burr. 2408. ${ }^{80}$ (1854) 4 H. L. C. *8I5.

${ }^{\infty}$ The state of judicial opinion is thus summed up by Erle, J., in Jefferys $v$. Boosey, supra, $81_{5}, * 875$, "In the learned conflict ending with Donaldson $v$. Beckett, the numbers for copyright at common law are in a great majority; Lord Mansfield, Aston, and Willes, Justices, against Yates in Millar v. Taylor; and ten Judges against one for copyright at common law; and either eight Judges against three, or seven against four, for an action for infringement in Donaldson v. Beckett." Later Lords Kenyon and.Ellenborough were of the same opinion as Yates, J;; in Jefferys v. Boosey, Erle, Wightman, Maule, J. J., and Coleridge, C. J., were in favor of the view that copyright existed at common law; Jervis, C. J., Pollock, C. B., Parke, B., and Lords Brougham and St. Leonards were against it.

${ }^{91}$ Ibid., Erle, J., said that, "no record of an action on the case for infringement of copyright prior to the statute of Anne, has been found;" but there appears to be a reference to such an action in the Company of Stationers $v$. Parker (1685) Skin. 234-5, where it is said that in the Company of Stationers v. Wright (1683) the company brought an action on the case on their patents. "

${ }^{2}$ Jefferys $v$. Boosey, supra, 815, *870.
} 